\title{
ДЕЛОВИ ПОЈАСНИХ ГАРНИТУРА ОД 5. ДО 7. ВЕКА ИЗ НАРОДНОГ МУЗЕЈА КРУШЕВАЦ
}

\author{
Душан Рашковић \\ Беч \\ e-mail: raskovic.dusan@gmail.com $\mid$ Кратко саопштење \\ Примљено: 29. 4. 2020. УДК: 904:739.2”04/06”(497.11) \\ Прихваћено: 31. 7. 2020. 069.51:903.25”04/06”(497.11)
}

\begin{abstract}
Апстракт: Народни музеј Крушеваи поседује збирку од 22 примерка делова појасних гарнитура датованих у период од 5. до 7. века. Реч је углавном о бронзаним копчама типа Сучидава и бронзаним појасним апликацијама. Бронзане копче и пређице, без окова, са продуженим трном из збирке музеја у Крушевиу, делови су византијских појасних гарнитура. Миннијатурне копче су делови гарнитура за закопчавање обуће и копчање торбица за појас.
\end{abstract}

Кључне речи: рановизантијски период, копче типа Сучидава, апликаџије, копче, пређице

Појасне гарнитуре од 5. до 7. века у збирци Народног музеја Крушевац археолошка су сведочанства рановизантијског периода, историјске епохе настале под притиском Велике сеобе народа. То време ограничиле су две ратне катастрофе, хунски поход, четрдесетих година 5. века, и аварска најезда, током првих деценија 7. века. Ратна разарања потпуно су променила конфигурацију насељавања балканских провинција. Равничарска насеља су напуштена, а налази на брдским локалитетима, односно налази остатака висинских утврђених насеља показују прелазак на кастелијерски начина живота.

Археологија од 5. до 7. века, односно период рановизантијске археологије заокупио је рад археолошког одељења Народног музеја Крушевац током припрема за Трећу југословенску конференцију византолога, одржану у мају 2000. године, у Крушевцу. Наиме, међу пратећим активностима конференције византолога, крушевачки музеј се припремао за пратећу изложбу „Рановизантијска насеља у Крушевачком окружју”. Археолошка збирка крушевачког музеја, поред керамичког материјала прикупљеног рекогносцирањем, од занимљивијих артефаката рановизантијске епохе тада је поседовала тек неколико предмета, са локалитета Градиште у Пуховцу и локалитета Градац у Горњим Левићима. Да би се направила релевантна збирка рановизантијског периода, приступило се интензивнијем рекогносцирању и прику- 
пљању преко откупа и поклона. Такав начин прикупљања се показао више него успешан. На широком простору крушевачког окружја, од долине Јужне Мораве до Копаоничког региона, с прикупљањем предмета се наставило и након затварања ове изложбе, тако да данас примерци накита, новца, оружја и оруђа алата и појасне опреме, па и копчи и пређица, датованих у рановизантијски период, представљају део археолошке збирке Народног музеја Крушевац. Појасне гарнитуре и копче, што је тема овог рада, биле су излагане у сталној поставци Народног музеја Крушевац и помињане у литератури, али никада нису на прави начин, нити појединачно и целовито публиковане.

Што се тиче територијалног опсега подручја рада Народног музеја Крушевац, видимо да је реч о моравској долини и брдско-планинском окружењу, Јухора, Јастрепца и Копаоника. Ако то подручје сагледамо из историјско-географског угла, крушевачки крај је у орбити трију касноантичких римских провинција, Медитеранска Дакија, Прва Мезија и Дарданија. Ако се сагледа конфигурација терена, осовина простора Медитеранске Дакије је Јужна Морава, и та провинција се могла простирати до окружја Крушевца и Јастрепца. Провинција Прва Мезија је била на северу, односно северно од долине Западне Мораве, у Левчу и Шумадији, а Дарданија се простирала на западу и, како претпостављамо, пратила је ибарску долину и допирала до Копаоничке регије (Мócsy 1974, 274-276).

Налазишта од 5. до 7. века у широј околини Крушевца, па и налази копчи и пређица, лоцирана су углавном на брдском терену, на вишим подручјима (Рашковић 2002, 29-72). Северно од обале Западне Мораве, у Левчу на Гледићким планинама, налази се локалитет Градац у Доњем Дубичу, док се Градац у Брезовици налази на прелазу из Крушевачке у Краљевачку котлину. Градиште у Дупцима је на размеђи Расинске долине и Топлице, на падинама Копаоника. Укоса је на месту става Јужне Мораве и Западне Мораве, на Мојсињским планинама. Градиште у Љубинцима је на побрђу питоме Александровачке жупе. Градиште у Петини и Градиште у Златарима гравитирају ка Великом Јастрепцу, док је Градац у Бресници готово на врху Великог Јастрепца.

Треба истаћи чињеницу да је крушевачки крај археолошки недовољно истражен. Први конкретни корак у систематском истраживању рановизантијских локалитета Народног музеја Крушевац, стицајем околности, била су систематска археолошка ископавања на локалитету Бедем у селу Маскаре, започета 2001. године. ${ }^{1}$ Поред ископавања на локалитету Бедем

\footnotetext{
${ }^{1}$ Ентузијазам за археологију у Крушевцу је био толики да је чак захваљујући донацији 1999. године читав вишеслојни локалитет Бедем, у селу Маскаре, са значајним рановизантијским слојем постао власништво Народног музеја Крушевац.
} 


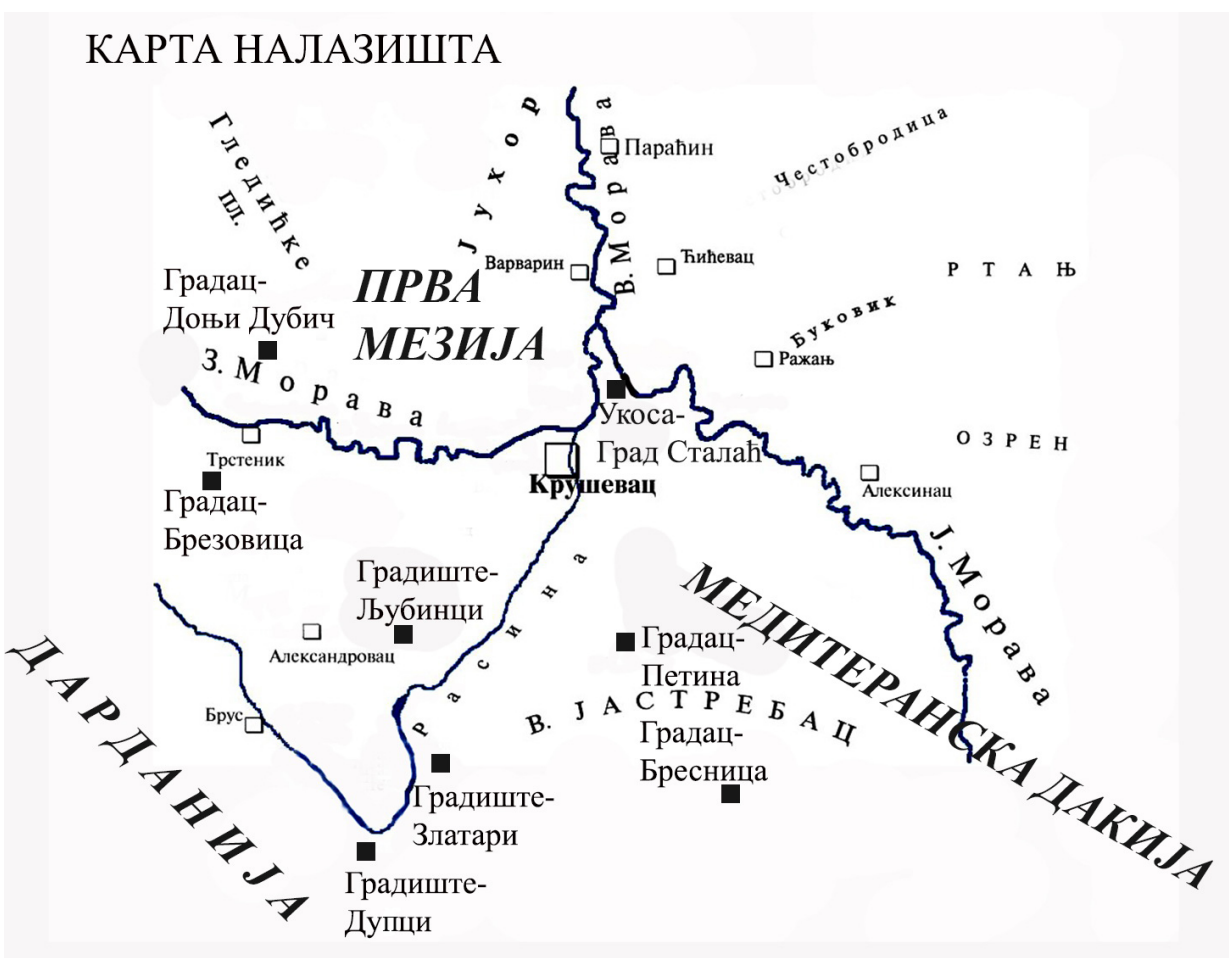

Карта 1. Карта налазишта

Map 1. Map of the site

(Бугар 2014, 197-214), археолошка ископавања спроведена су на пет рановизантијских локалитета у окружју Крушевца. Најзначајнија истраживања су систематска ископавања Регионалног завода за заштиту споменика културе из Краљева, локалитета Небеске столице на Копаонику, започета 1998. године. Захваљујући њима Копаоник и околина се налазе међу најзанимљивијим подручјима у Србији када је реч о раносредњовековној археологији (Тошић, Рашковић 2007, 27-45). Не треба заборавити прва археолошка ископавања рановизантијског утврђења, која је спровео Регионални завод за заштиту споменика културе из Краљева у окружју Копаоника; ископавања на локалитету Градиште на брду Гобеља код Бруса, из 1987. године (Богосављевић-Петровић, Рашковић 2001, 99-121), и мању кампању на локалитету Градац у селу Горње Левиће, из 2005. године, што све потврђује значај брдског копаоничког краја у периоду од 5. до 7. века. Поред ископавања на Бедему у селу Маскаре, у окружју саставака Јужне Мораве и Западне Мораве, сондажна ископавања су спроведена на локалитету Укоса у селу Град Сталаћ, на Јужној Морави (Рашковић 2016а, 285-303). 
Археолошка ископавања спроведена у околини Крушевца занимљива су због елемената из периода настанка и пропасти рановизантијске власти у централној Србији, али та ископавања за наш рад на тему о копчама и пређицама нису била од користи као у случају поклона и откупа. Изузетак су ископавања локалитета Укоса, где је 2009. године пронађен један примерак копче типа Сучидава, чиме ћемо почети овај преглед.

\section{Копче типа Сучидава}

Копче типа Сучидава су налази типични за рановизантијски период, током 6. и почетком 7. века, на локалитетима широм ромејске државе, а по броју се истиче основни облик D1 копче типа Сучидава (Werner 1955, 49-50). Исто је и на подручју Србије. Ту су примери копчи пронађених у Неготинској Крајини (Јанковић 1981, 175) на подручју Пчињског округа (Mitrović 2010, 99), Сокобањске котлине (Рашковић 2016b, 32-34) и на археолошким налазиштима Ђердапа (Špehar 2010, 54-55). Копче Народног музеја Крушевац се уклапају у општу слику распростирања налаза копчи типа Сучидава. То су омање бронзане једноделне копче, ливене из једног дела, са квадратном алком и овалним оковом (Madgearu 1998, 2). Украшене су на пробој, са крстоликим мотивом и полумесечастим мотивом испод. Крстолики мотив је изведен у варијантама са оштрим угловима или облим завршецима. На полеђини су три ушице за причвршћивање на каиш. Копче Народног музеја Крушевац добро су очуване, осим у случају налаза са Градишта у Златарима, који је у већем делу оштећен. У два случаја сачуван је и профилисани трн на пређици.

На локалитету Градац код Бресничког језера пронађена је копча типа Сучидава са облом али делимично оштећеном алком и штитастим оковом, украшена на пробој у облику три тачке и полумесецом (Т. II/1). Према класификацији Л. Ангелове Трајкове, копчу датујемо у другу половину 6. века и прву половину 7. века (Ангелова Трайкова 2017, 87, тип, VIII b2).

\section{Каталог:}

1) Једноделна копча са правоугаоном алком и фиксираним штитастим оковом типа Сучидава. Бронза, ливење са проламањем. Мотив крста облих крајева и полумесеца. Делимично очувана, недостаје трн. Датовање. Димензије: дужина: 4,7 цм, ширина 2,8 цм. Место налаза: Укоса у селу Град Сталаћ (Рашковић 2016а, 291). Т. I/1

2) Једноделна копча са правоугаоном алком и фиксираним штитастим оковом типа Сучидава. Бронза, ливење са проламањем, знатно оштећена. 
Сачуван је део мотива крста и полумесеца. Сачуване димензије: дужина 3,7 цм, ширина 2,8 цм. Место налаза: Градиште у селу Златари (Тошић, Рашковић 2009, 186). Т. I/2

3) Једноделна копча са правоугаоном алком и фиксираним штитастим оковом типа Сучидава. Делимично сачувана, без игле. Бронза, ливење са проламањем. Мотив крста оштрих крајева и полумесеца. Димензије: дужина: 4,8 цм, ширина, 2,6 цм. Место налаза: Градац у селу Брезовица (Рашковић 2014, 240). Т. I/3

4) Једноделна копча са правоугаоном алком и фиксираним штитастим оковом типа Сучидава. Цела сачувана са профилисаним трном. Бронза, ливење са проламањем. Мотив крста оштрих крајева и полумесеца. Димензије: дужина: 4,7 цм, ширина 2,5 цм. Место налаза: Градиште у селу Дупци (Тошић, Рашковић 2009, 186). T. I/4

5) Једноделна копча са правоугаоном алком и фиксираним штитастим оковом типа Сучидава. Трн није сачуван. Бронза, ливење са проламањем. Мотив крста облих крајева и полумесеца. Димензије: дужина, 4,1 цм, ширина 3,1 цм. Место налаза: Градиште у селу Петина (Тошић, Рашковић 2009, 186). Т. I/5

6) Једноделна копча са правоугаоном алком и фиксираним штитастим оковом типа Сучидава. Потпуно очувана са профилисаним трном. Бронза, ливење са проламањем. Мотив крста оштрих крајева. Димензије: дужина: 3,8 цм, ширина 2,4 цм. Место налаза: Градиште у селу Петина (Тошић, Рашковић 2009, 186). Т. I/6

7) Копча типа Сучидава са облом али делимично оштећеном алком и штитастим оковом. Бронза, ливење са проламањем. Мотив у виду три круга и полумесеца. Димензије: висина 4,5 цм, ширине 2,5 цм. Место налаза Градац код села Бресница (Рашковић 2016б, 31). Т. II/1

\section{Појасне апликације}

Четири примерка појасних апликација Народног музеја Крушевац, које датујемо у период од 5. до 7. века, пронађене су на два локалитета рановизантијских утврђења у крушевачком окружју, на Градишту у селу Петина под Великим Јастрепцом и Градишту у селу Љубинци, у Александровачкој жупи. Реч је о апликацијама штитастог облика, украшених на проламање.

Занимљив је и налаз делимично сачуване бронзане Т-апликације, из збирке крушевачког музеја, украшене на проламање, пронађене на локалитету Градиште у Љубинцима (Т. II/2). Такве апликације датујемо у другу половину 6. до почетка 7. века (Ангелова Трайкова 2017, 133, кат. бр. 1564, тип XV). 
На вишеслојном локалитету у вишим подручјима, на Градишту у Љубинцима код Александровца Жупског, пронађене су три штитасте појасне апликације. Реч је о апликацијама украшеним идентично на проламање, са по два наспрамно постављена полумесечаста мотива и две тачке између. Копче датујемо у другу половину 6. века (Ангелова Трайкова 2017, 126, кат. бр. 1427-29, тип II b1). Две копче део су налаза нелегалних трагача са локалитета Градиште у Љубинцима, које је полиција запленила 2007. године (Рашковић, Димовска и Црнобрња 2010, 37). Једна од три идентичне апликације, са Градишта у Љубинцима, чува се у крушевачком музеју. Детаљ по ком се разликује само је једна тачка између полумесечастих мотива (Т. II/5).

Појасна апликација, која потиче са локалитета Градиште у Петини, под Великим Јастрепцом, истог је штитастог облика као и три апликације пронађене на Градишту у Љубинцима (Т. II/4). Украшена на проламање, али за разлику од примерака из Љубинаца, са крстастим и полумесечастим мотивом и са два окаста удубљења, на врху, са страна (Samu 2018, 235, Taf. 1,VI, 59).

Са локалитета у Петини под Јастрепцом потиче и налаз минијатурне апликације, дела појасне опреме, украшен такође на проламање, са мотивом маске (T. II/3), карактеристичним за другу половину 6. и почетак 7. века (Ангелова Трайкова 2017, 125).

\section{Каталог:}

1) Део појасне Т-апликације, са одломљеним тракастим наставком округлог пресека. Бронза, ливење са проламањем. На штитастом делу украс на проламање, у виду тачака поређаних у полумесечастом и окомитом низу, са две тачке и водоравном траком на врху. На полеђини штитастог дела су три ушице за качење. Горњи део сломљен, сачуван део тракастог наставка. Димензије: сачувана дужина 4,8 цм, ширина 2,7 цм. Место налаза: Градиште у селу Љубинци (Рашковић, Димовски и Црнобрња 2010, 31-32). T. II/2

2) Минијатурна апликација. Бронза, ливење са проламањем, са мотивом маске. Димензије: висина 2,5 цм, ширина 2,1 цм. Датовање друга половина 6. века. Место налаза: Градиште у селу Петини (Рашковић 2014, 240). T. II/3

3) Појасна апликација. Бронза, ливење са проламањем. Мотив крста облих крајева и полумесеца, са два окаста удубљења са страна. Димензије: висина 3,8 цм, ширина 3,5 цм. Место налаза: Градиште у селу Петини (Рашковић 2014, 240). Т. II/4 
4) Појасна апликација. Бронза, ливење са проламањем. Мотив два наспрамно постављена полукруга и једна тачка између. Димензије: висина 3,9 цм, ширина 3,2 цм. Место налаза: Градиште у селу Љубинци. Т. II/5

\section{Копче са продуженим трном}

Украшавању ремења у појасном делу, као и ремења пребаченог преко рамена, придавана је највећа пажња у касноантичком и рановизантијском периоду. Копче су биле незаобилазан део ношње која је као део војне опреме била наметнута милитаризацијом друштва. Бронзане ливене копче без окова, са наглашеним трном, карактеристични су налази на локалитетима рановизантијских насеља. Три бронзане пређице са продуженим трном, једна гвоздена и један трн без копче пронађени су на локалитетима утврђења у околини Крушевца и налазе се у збирци Народног музеја Крушевац.

Пажњу привлаче две рановизантијске копче елипсоидног облика, са стањеном задњом страном за уметање трна. Оне потичу са локалитета Брусови, смештеног у зони локалитета Градац у Брезовици, на око 500 м источно од утврђења. Једна од копчи је са равно одсеченим продуженим трном, троугаоног пресека (Т. III/1). Друга копча елипсоидног облика, са истог локалитета, бронзана је копча са продуженим трном овалног пресека (Т. III/2). Облици одговарају рановизантијским копчама, датованим у прву половину 6. века (Schulze-Dörrlamm 2009, 16-18; Ангелова Трайкова 2017, 112, кат. бр. 117). Постоје аналогије које упућују и на варварски утицај на облик ових копчи (Ангелова Трайкова 2017, 112). Слични налази потичу и са германске некрополе у Раковчанима код Приједора (Miletić 1970, 149, T. IV, 33).

Овалну копчу са Градишта у Дупцима, у збирци крушевачког музеја, директно везујемо за германске копче 5. и 6. века, што би могао бити прилог германским налазима на простору централне Србије (Milinković 2011, 129-141). Реч је о бронзаној копчи, са масивним продуженим трном (T. III/3). Аналогије видимо међу налазима карактеристичним за оставштину Источних Гота на Балканском полуострву (Mrkobrad 1980, 36).

Гвоздену копчу са бубрежастом и профилисаном алком са равним, продуженим трном, пронађену такође на Градишту у селу Дупци, датујемо у другу половину 6. и прву половину 7. века (T. III/4). Аналогије налазимо у копчи пронађеној у околини Варне (Ангелова Трайкова 2017, 53, кат. бр. 364) и византијским копчама с подручја Мале Азије (Schulze-Dörrlamm 2009, 68-78, тип, В15-В18).

У ову групу налаза можемо додати и трн са повијеним крајем који је прелазио преко пређице, израђен од сребра, у чијем се корену налази пра- 
воугаоно лежиште за стаклени уметак (T. III/5). Недостаје део са куком за причвршћивање на носач. ${ }^{2}$ Аналогију за овакав облик трна са правоугаоним лежиштем за стаклени уметак налазимо у југозападној Бугарској, на локалитету Кошарево, где је у гробу германског ратника, датованог у другу половину 5. века, пронађена копча са истим типом трна (Schulze-Dörrlamm $2009,310-311)$. Више копчи са идентичним типом трна налазимо на германским налазиштима у Другој Панонији (Tejral 2015, 332). Можда бисмо могли у вези са овим налазом из Љубинаца, због историјског контекста, поменути и добро познату златну копчу пронађену у Крушевцу, датовану у 5. век. Она се приписује Источним Готима, а чува се у Народним музеју у Београду (Вински 1964, 173).

\section{Каталог:}

1) Копча елипсоидног облика и равно одсеченим продуженим трном, троугаоног пресека, који кљунастим завршетком прелази преко алке. Трн петљом привезан за носач. Бронза ливење. Димензије: висина 3,3 цм, ширина 3,4 цм. Место налаза: Градац у Брезовици - Брусови (Рашковић 2014, 240). T. III/1

2) Копча елипсоидног облика, округлог пресека, са продуженим трном, који кљунастим завршетком прелази преко алке. Трн петљом привезан за носач. Бронза ливење. Димензије: висина 3,1 цм, ширина 2,7 цм. Место налаза: Градац у Брезовици - Брусови (Рашковић 2014, 240). Т. III/2

3) Овална копча, са кружном алком округог пресека. Масивни продужени трн, округлог пресека, прелази преко обле алке. Трн је петљом причвршћен за носач. Бронза ливење. Димензије: висина 3,6 цм, ширина 2,7 цм. Место налаза: Градиште у Дупцима (Рашковић 2014, 240). Т. III/3

4) Копча са профилисаном пређицом бубрежастог изгледа и стањеном површином за уметање трна. Задњи део трна савијен попут куке и тако причвршћен на носач. Наглашен продужени, кљунасти трн, полукружног пресека. Гвожђе ковање. Димензије: висина 2,8 цм, ширина 4 цм. Место налаза: Градиште у Дупцима (Рашковић 2014, 240). Т. III/4

5) Сребрни трн са повијеним крајем, који је прелазио преко пређице, у чијем се корену налази правоугаоно лежиште за стаклени уметак, дужине 3,1 цм. Место налаза: Градиште у Љубинцима (Рашковић 2014, 240). T. III/5

\footnotetext{
${ }^{2}$ Трн је део налаза више предмета; током нелегалног рада на локалитету Градиште у селу Љубинци групу трагача је осујетила и предмете им одузела полиција.
} 


\section{Копче за обућу и за копчање торбица за појас}

Један од сегмената збирке рановизантијских копчи Народног музеја Крушевац, које у овом раду издвајамо, јесу копче мањих димензија, којима се закопчавала обућа, али и прикопчавале торбице за појас. У збирци Народног музеја Крушевац, постоји више копчи мањих димензуја углавном датованих у касноантички период. Међутим, део примерака датујемо у период од 5. до 7. века. На основу њиховог облика, као и места налаза, на локалитетима са рановизантијским слојем, ове пређице мањих димензија датују се у рановизантијски период.

Као аналогије за копче мањих димензија, било за копчање обуће или торбица за појас, могу послужити копче пронађене међу гробним налазима германске некрополе на локалитету Раковчани код Приједора (Miletić 1970, 150, T III/18, T IV/43).

Народни музеј Крушевац чува шест примерака, пређица, делова мањих копчи. Четири примерка су пронађена на локалитету Градац у селу Доњи Дубич недалеко од манастира Љубостиња. Од тога су три примерка, са локалитета у Доњем Дубичу, карактеристичне масивне пређице, са стањеним делом за уметање трна (T. IV/I, II, III), које датујемо у 5. и 6. век (Ангелова Трайкова 2017, 112). На истом локалитету у Доњем Дубичу, пронађена је и цела сачувана копча са елипсоидном пређицом и стањеним делом за уметање равног трна, који прелази преко алке (T. IV/4), датована у другу половину 5. века до прве половине 6. века (Ангелова Трайкова 2017, 112, кат. бр. 1101-04).

Два примерка из збирке Народног музеја Крушевац потичу са локалитета Градиште у Љубинцима, код Александровца. Мања гвоздена копча са делимично сачуваним оковом од гвозденог лима (T. IV/5) и елипсоидна пређица са равним стањеним делом за уметање трна (T. IV/6) датују се у 5. и 6. век (Ангелова Трайкова 2017, 111-112. кат. бр. 1077-79).

\section{Каталог:}

1) Пређица елипсоидног облика, са стањеном површином за уметање трна. Трн није сачуван. Бронза ливење. Димензије: висина 2,0 цм, ширина 1,4 цм (Рашковић, Тошић 2009, 76). T. IV/1

2) Пређица елипсоидног облика, са стањеном површином за уметање трна. Трн није сачуван. Бронза ливење. Димензије: висина 1,6 цм, ширина 1,1 цм (Рашковић, Тошић 2009, 76). T. IV/2

3) Пређица, елипсоидног облика, са стањеном површином за уметање трна. Трн није сачуван. Бронза ливење. Димензије: висина 1,8 цм, ширина 1,2 цм (Рашковић, Тошић 2009, 76). T. IV/3 
4) Копча елипсоидног облика, цела сачувана, са продуженим равним трном округлог пресека. Задњи део трна савијен попут куке и тако причвршћен на носач. Бронза ливење. Димензије: дужина 2,3 цм, ширина 2,1 цм (Рашковић, Тошић 2009, 76). T. IV/4

5) Минијатурна гвоздена копча, цела сачувна са овалном пређицом и трном, са стањеном површином за уметање трна. Димензије: висина 2,0 цм, ширина 1,4 цм (Рашковић, Димовски и Црнобрња 2010, 31-32). Т. $\mathrm{IV} / 5$

6) Пређица елипсоидног облика, са стањеном површином за уметање трна. Трн није сачуван. Бронза ливење. Димензије: висина 2,0 цм, ширина 1,4 цм (Рашковић, Димовски и Црнобрња 2010, 31-32). T. IV/6

\section{Уместо закључка}

Током 5. века римска насеља силом историјских околности прелазе на брдске просторе, на висове, унутар мање или више тврдих градских зидина (Милинковић 2015). Унутар бедема заштићених насеља, услед рата, сеоба и мешања народа, створени су нови обичаји и нови облици материјалне културе. Контакти Ромеја са германским племенима, током Велике сеобе народа, завршиће симбиозом ромејске и германске цивилизације. Копче и прећице, као специфичан део ношње, сведоче, између осталог, и прожимању култура, присутном у животу у подручјима на вишим надморским висинама, од 5. до 7. века у Србији и у крушевачком крају.

Међутим, морамо се суочити са чињеницом да двадесетак случајних налаза у крушевачком музеју не могу заменити недовољну истраженост рановизантијске археологије. У том погледу светла тачка у раду Народног музеја Крушевац јесу археолошки радови у зони става Јужне и Западне Мораве, где је Народни музеј Крушевац подузео археолошка ископавања на два локалитета, Бедем у селу Маскаре и Укоса у селу Град Сталаћ. Ова ископавања су изнедрила археолошке резултате који заслужују пажњу. Откриће рановизантијске цркве, остава новца 5. века, јаме и керамичка пећ и ситни налази, међу којима је и једна копча типа Сучидава, наговештавају боље дане. Чак мислимо да су се захваљујући новим резултатима на пољу археологије од 5. до 7. века и резултатима ископавања Регионалног завода за заштиту споменика културе из Краљева на локалитету Небеске столице на Копаонику стекли услови да Народни музеј Крушевац, након 20 година рада на прикупљању археолошке грађе, обнови изложбу из маја 2000. године „Рановизантијска насеља у Крушевачком окружју”. 


\section{БИБЛИОГРАФИЈА}

Ангелова Трайкова, Л. 2017. Коланът южно от Долен Дунав - края на III - началоmо на VII в, (Дисертации, том 10), Националният археологически институт, София.

Богосављевић-Петровић, В., и Рашковић, Д. 2001. Рановизантијско утврђење на брду Гобеља код Бруса, Саопштења, Београд: 99-120.

Бугар, М. 2014. Рановизантијска базилика на локалитету Бедем, Зборник Народног музеја Крушеваи, 16, Крушевац: 197-214.

Vinski, Z. 1964. Okov Teodorikova vremena sa ostrva Sapaja na Dunavu, Zbornik Narodnog muzeja, IV, Beograd: 173.

Janković, Đ. 1981. Podunavski deo oblasti Akvis u VI i početkom VII veka, Beograd: 175. Madgearu, A. 1998. The Sucidava tipe of Buckles and the relations between the Late Roman and Barbariens in the 6-th Century, Arheologia Moldovei, 21, Iasi: 217-222.

Miletić, N. 1970. Ranosrednjovjekovna nekropola u Rakovčanima kod Prijedora, Glasnik Zemaljskog muzeja u Sarajevu, XXV, Sarajevo: 119-177.

Milinković, M. 2011. Völkerwanderungszeitliche Funde und Befunde im heutigen Serbien unter besonderer Berücksichtigung von Gamzigrad, in: Bruckneudorf und Gamzigrad. Spätantike Paläste und Großvillen im Donau-Balkan-Raum. Akten des Internationalen Kolloquiums in Bruckneudorf vom 15. bis 18. Oktober 2008, Hrsg. G. v. Bülow-H. Zabehlicky, Bonn: 129-141.

Милинковић, М. 2015. Рановизантијска насеља у Србији и њеном окружеюу, Београд. Mitrović, G. 2010. Katalog metala I, Vranje: 99.

Mócsy, A. 1974. Pannonia and Upper Moesia, London: 274-275.

Mrkobrad, D. 1980. Arheološki nalazi seobe naroda u Jugoslaviji, Beograd: 36.

Рашковић, Д. и др. 2000. Рановизантијска утврђења у крушевачком окружју (Каталог изложбе), Крушевац.

Рашковић, Д. 2002. Рановизантијски археолошки локалитети и комуникације у ширем крушевачком окружју, у Љ. Максимовић и др. [ур.], Трећа југословенска конференција византолога: Крушевац, 10-13. мај 2000. (Зборник радова), КрушевацБеоград: 29-72.

Рашковић, Д. и Тошић, Г. 2009. Прилог познавању касноантичких и средњовековних утврђења у околини Каленића, у Калић J. [ур.] Манастир Каленић у сусрет шестој стогодишњиц̧и, Научни скуп, 5-6. октобар, 2008, Каленић, Београд, САНУ - Одељење историјских наука, Београд-Крагујевац: 76.

Рашковић, Д., Димовски, Н. и Црнобрња, С. 2010. Рановизантијско утврђење Градиште у Љубинцима - Жупа Александровачка, Жупски зборник, 5, Александровац: 29-52.

Рашковић, Д. 2014. Антички археолошки локалитети у широј околини Манастира Љубостиња, у Мишић, С. и Јечменица, Д. [ур.], Кнегиња Милица-монахиња Јевгенија и њено доба, Тематски зборник радова са научног симпозијума одржаног 12. септембра 2014. године у манастиру Љубостиња, Трстеник: 240 
Рашковић, Д. 2016а. Налази из рановизантијског и средњовековног периода на локалитету Укоса у Граду Сталаћу, Гласник Српског археолошког друштва, 32, Београд: 285-303.

Рашковић, Д. 2016б. Низинска античка насеља и висинска рановизантијска налазишта у окружју Алексинца и Соко Бање, Караиић, 8, Алексинац: 33-35.

Samu, L. 2018. Über die Zusammenhänge den Gürtelschnallen mit festem Beschlag und Motiven in Durchbruchornamentik und den Gürtelbeschlägen der zweiten Hälfte des 6. und beginnenden 7. Jahrhunderts, 26th Conference of Young Scholars on the Migration Period, Disertationes Archaeologicae, Suplementum, 2, Budapest: 233-256.

Schulze-Dörrlamm, M. 2009. Byzantinische Gürtelschnallen und Gürtelbeschläge im Römisch-Germanischen Zentralmuseum. Kataloge RGZM, 30, 1-2, Mainz.

Špehar, P. 2010. Materijalna kultura ranovizantijskih utvrđenja u Đerdapu, Beograd: 54-55.

Tejral, J. 2015. Zum Problem der Feinschmiedeproduktion im Mitteldonauraum während des 5. Jahrhunderts nach Chr., Pamatky Archeologicke, CVI, Prague: 332.

Тошић, Г. и Рашковић, Д. 2007. Ранохришћански споменици на источним падинама Копаоника, Зборник радова Византолошког института, 44/1, Београд: 27-45.

Тошић, Г. и Рашковић, Д. 2009. Хришћански мотиви на археолошком материјалу из околине Крушевца и Алексинца, Ниш и Византија, VII, Ниш:186.

Werner, J. 1955. Byzantinische Gürtelschnallen des 6. und 7. Jahrhunderts aus der Sammlung Diergardt, Kölner Jahrbuch für Vor- und Frühgeschichte, I, Berlin: 49-50. 


\title{
Dušan Rašković
}

Vienna

\section{PARTS OF BELT SETS FROM THE $5^{\mathrm{TH}}$ UP TO THE $7^{\mathrm{TH}}$ CENTURY FROM THE ARCHAEOLOGICAL COLLECTION OF THE NATIONAL MUSEUM OF KRUŠEVAC}

\author{
Keywords: Early Byzantine period, Sucidava type bucle, \\ belt-applications, buckles, belt-rings
}

The National Museum of Kruševac has a collection consisting of 22 examples of parts of belt sets, dated into the period from the $5^{\text {th }}$ up to the $7^{\text {th }}$ century. Those are mostly bronze buckles of the Sucidava type and bronze belt applications. Bronze buckles with extended thorns, from the collection of the Museum of Kruševac, were parts of Byzantine belt sets. Miniature buckles were parts of sets for fastening footwear and fastening belt sashes. Certain examples display traits of the barbarian style from the period of the Great Migration.

During the $5^{\text {th }}$ century, Roman settlements moved, due to historical circumstances, to hill areas, and elevated locations, within more or less fortified city walls (Милинковић 2015). Inside those settlements protected by ramparts, a period of war, migration and mixing of peoples lead to the creation of new customs and new forms of material culture. Contacts between the Romaians with German tribes, in the period of the Great Migration, would end in a symbiosis of the Romaian and German civilizations. Buckles and belt-rings, as a specific part of traditional costumes, bear witness, among other things, on the intertwining of cultures, present in the life on mountainous areas, from the $5^{\text {th }}$ up to the $7^{\text {th }}$ century, in Serbia and the Kruševac region.

We must face, however, the fact that ca twenty accidental findings from the Museum of Kruševac cannot compensate for the insufficient research level of Early Byzantine archaeology. In this sense, a bright spot in the work of the National Museum of Kruševac are archaeological works in the zone of the confluence of the Južna Morava and Zapadna Morava, where the National Museum of Kruševac undertook archaeological excavations on two sites, Bedem, in the village of Maskare, and Ukosa, in the village of Grad Stalać. These excavations yielded results worthy of attention. The discovery of an Early Byzantine church, a hoard of coins from the $5^{\text {th }}$ century, pits and a ceramic kiln, as well as small findings, among which was one buckle of the Sucidava type, bring hope for some better days. We even believe that thanks to the new results in the field of archaeology 
of the period from the $5^{\text {th }}$ and the $7^{\text {th }}$ century and thanks to the results achieved by the regional Cultural Monument Protection Institute from Kraljevo at the site of Nebeske Stolice at the mount Kopanik, it would be possible for the National Museum of Kruševac to finally, after 20 years of gathering archaeological material, restore the exhibition from May 2000 entitled "Early Byzantine settlements in the region of Kruševac" ("Ranovizantijska naselja u Kruševačkom okružju”). 


\section{T.I}
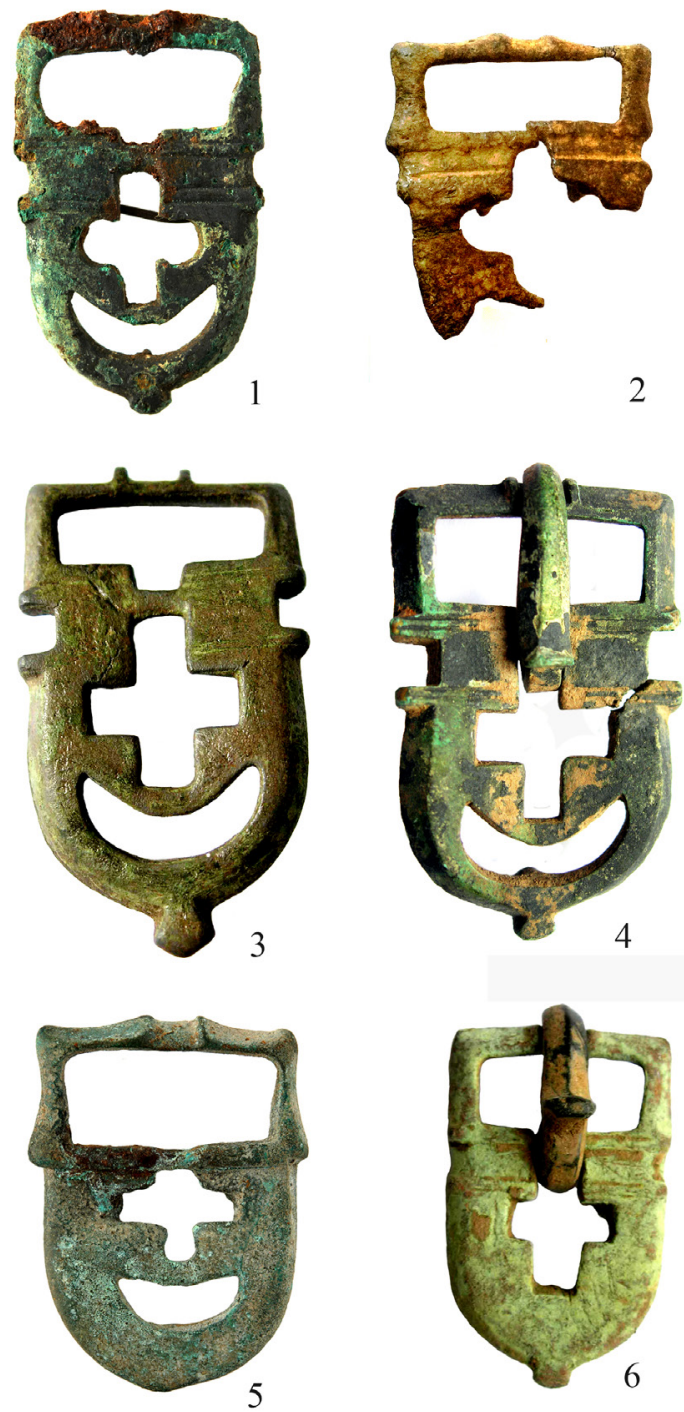

T. I 1. Копча типа Сучидава. Локалитет Укоса у селу Град Сталаћ; 2. Копча типа Сучидава. Локалитет Градиште у селу Златари; 3. Копча типа Сучидава. Локалитет Градац у селу Брезовица; 4. Копча типа Сучидава. Локалитет Градиште у селу Дупци; 5. Копча типа Сучидава. Локалитет Градиште у селу Петина; 6. Копча типа Сучидава. Локалитет Градиште у селу Петина.

Pl. I 1. Sucidava type buckle. Site of Ukosa in the village of Grad Stalać; 2. Sucidava type buckle. Site of Gradište in the village of Zlatari; 3. Sucidava type buckle. Site of Gradac in the village of Brezovica; 4. Sucidava type buckle. Site of Gradište in the village of Dubci; 5. Sucidava type buckle. Site of Gradište in the village of Petina; 6. Sucidava type buckle. Site of Gradište in the village of Petina. 

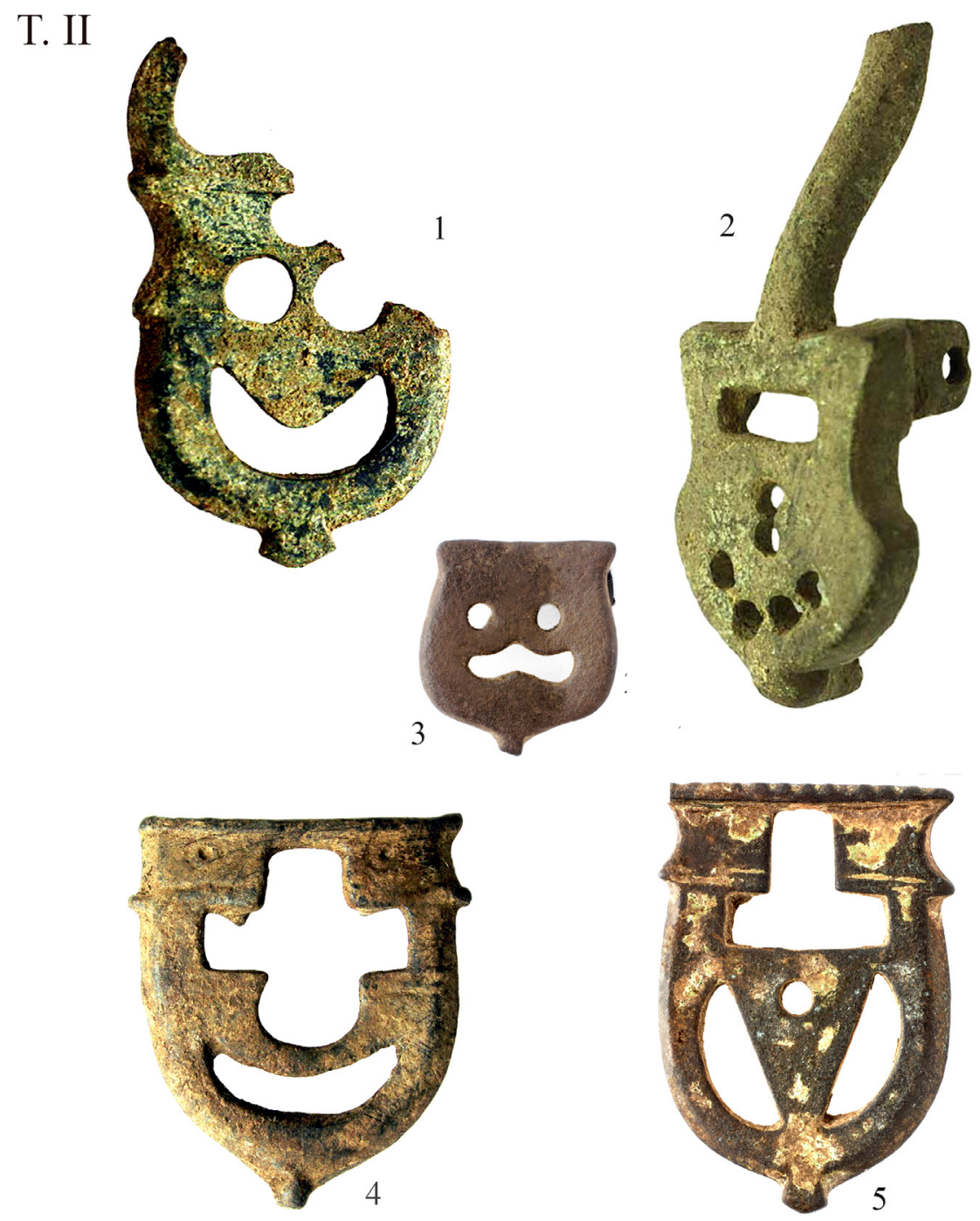

T. II 1. Копча типа Сучидава. Локалитет Градац у селу Бресница; 2. Део појасне Т-апликације. Локалитет Градиште у селу Љубинци; 3. Минијатурна апликација. Локалитет Градиште у селу Петина; 4. Појасна апликација. Локалитет Градиште у селу Петина; 5. Појасна апликација. Локалитет Градиште у селу Љубинци.

PI. II 1. Sucidava type buckle. Site of Gradac in the village of Bresnica; 2. Part of a Tshaped belt application. Site of Gradište in the village of Ljubinci; 3. Miniature application. Site of Gradište in the village of Petina; 4. Belt application. Site of Gradište in the village of Petina; 5. Belt application. Site of Gradište in the village of Ljubinci. 
T. III
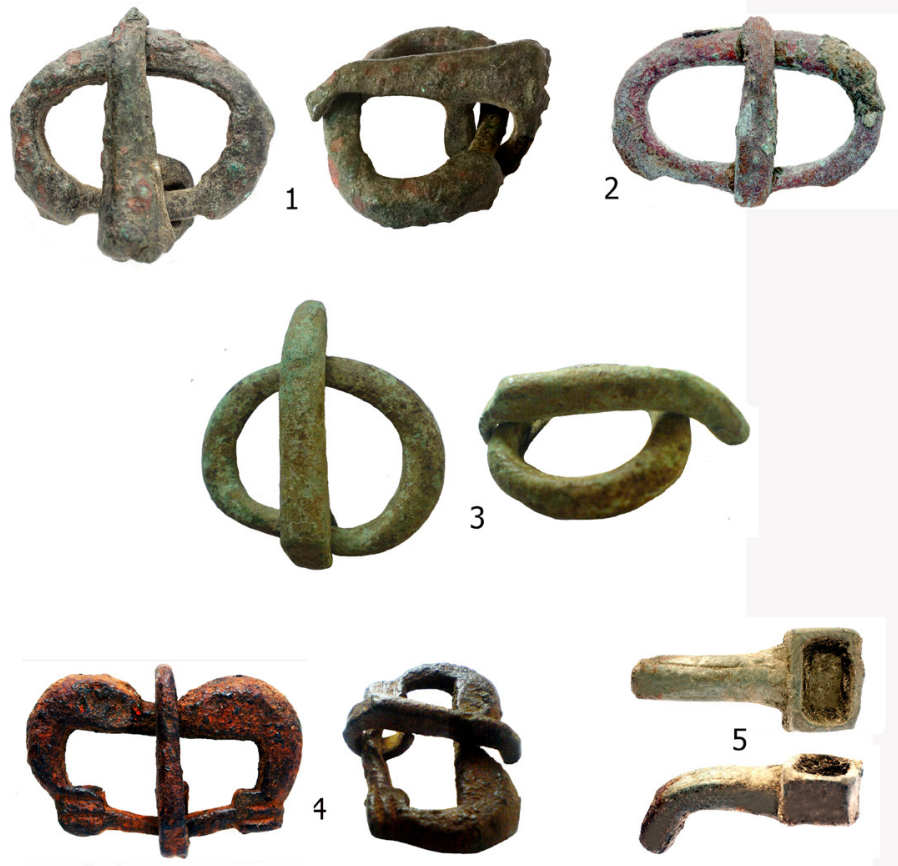

T. III 1. Копча елипсоидног облика. Локалитет Градац у селу Брезовица (Брусови); 2. Копча елипсоидног облика. Локалитет Градац у селу Брезовица (Брусови); 3. Копча са овалном алком. Локалитет Градиште у селу Дупци; 4. Копча са профилисаном алком. Локалитет Градиште у селу Дупци; 5. Трн са повијеним крајем и правоугаоним лежиштем за стаклени уметак. Локалитет Градиште у селу Љубинци.

PI. III 1. Elliptical buckle. Site of Gradac in the village of Brezovica (Brusovi); 2. Elliptical buckle. Site of Gradac in the village of Brezovica (Brusovi); 3. Buckle with an oval hoop. Site of Gradište in the village of Dubci; 4. Buckle with a profiled hoop. Site of Gradište in the village of Dubci; 5. Thorn with a bent end and rectangular groove for a glass implant. Site of Gradište in the village of Ljubinci. 


\section{T. IV}
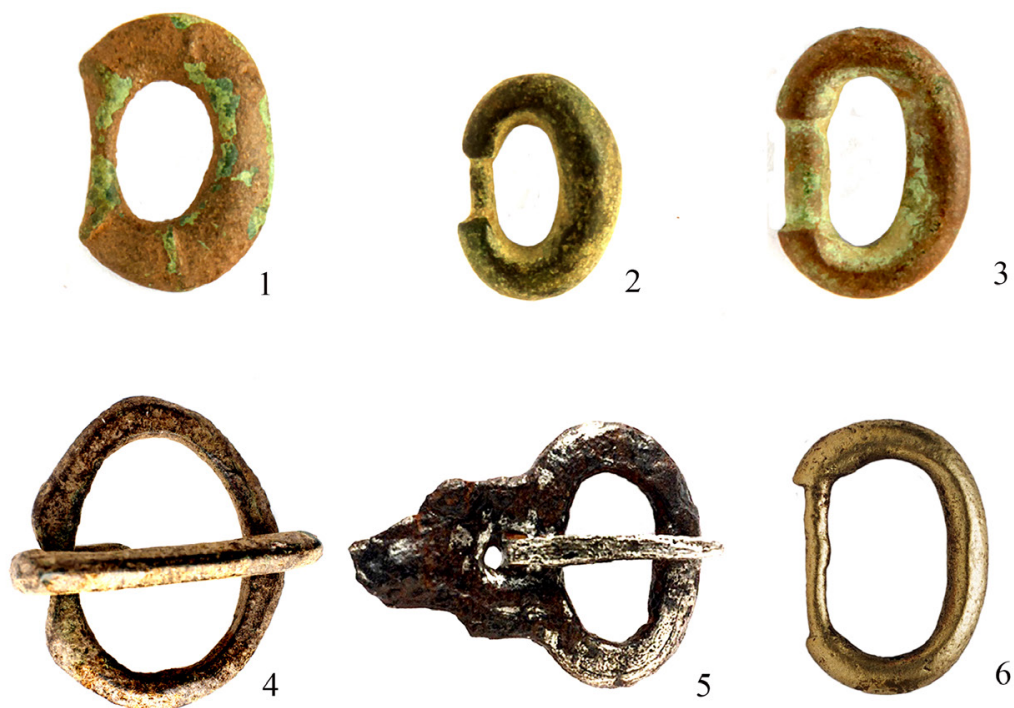

T. IV 1. Пређица елипсоидног облика. Локалитет Градац у селу Доњи Дубич; 2. Пређица елипсоидног облика. Локалитет Градац у селу Доњи Дубич; 3. Пређица елипсоидног облика. Локалитет Градац у селу Доњи Дубич; 4. Копча елипсоидног облика. Локалитет Градац у селу Доњи Дубич; 5. Гвоздена копча. Локалитет Градиште у селу Љубинци; 6. Пређица елипсоидног облика. Локалитет Градиште у селу Љубинци.

PI. IV 1. Elliptical belt-ring. Site of Gradac in the village of Donji Dubič; 2. Elliptical belt-ring. Site of Gradac in the village of Donji Dubič; 3. Elliptical belt-ring. Site of Gradac in the village of Donji Dubič; 4. Elliptical buckle. Site of Gradac in the village of Donji Dubič; 5. Iron buckle. Site of Gradište in the village of Ljubinci; 6. Elliptical beltring. Site of Gradište in the village of Ljubinci. 